\title{
Comparison of anti-inflammatory effects of Mecasin and its constituents on lipopolysaccharide-stimulated BV2 cells
}

\author{
TINGTING WANG ${ }^{1 *}$, WONMIN KO ${ }^{2 *}$, JOON-YEONG SHIN $^{3}$, DONGHO CHOI $^{3}$, \\ DONG-SUNG LEE ${ }^{2}$ and SUNGCHUL KIM ${ }^{1,3}$ \\ ${ }^{1}$ ALS/MND Center of Wonkwang University Gwangju Korean Medicine Hospital, Gwangju 61729; \\ ${ }^{2}$ Department of Pharmacy, Chosun University, Dong-gu, Gwangju 61452; ${ }^{3}$ Professional Graduate School, \\ Wonkwang University, Jeonbuk, Iksan 54538, Republic of Korea
}

Received April 9, 2020; Accepted February 15, 2021

DOI: $10.3892 /$ etm. 2021.10023

\begin{abstract}
Mecasin, a traditional medicine, contains nine herbal constituents: Curcuma longa, Salvia miltio rhiza, Gastrodia elata, Chaenomeles sinensis, Polygala tenuifolia, Paeonia japonica, Glycyrrhiza uralensis, Atractylodes japonica and processed Aconitum carmichaeli. Several biological effects of mecasin have been described both in vivo and in vitro. Previous studies have demonstrated that mecasin has anti-inflammatory effects. The purpose of the present study was to determine anti-inflammatory effects of mecasin and its natural product constituents on lipopolysaccharide (LPS)-stimulated BV2 cells by measuring nitrite and nitric oxide contents. Nitrite production levels in LPS-stimulated BV2 cells incubated with mecasin and each individual constituent of mecasin were measured. The results suggested that $C$. longa, $P$. tenuifolia and $P$. japonica inhibited nitrite production in a pattern similar to that of mecasin. The effect of mecasin was likely a result of synergistic effects of its natural herb constituents.
\end{abstract}

\section{Introduction}

Microglia are widely distributed in the brain and spinal cord. Immune abnormalities occurring in degenerative diseases of the central nervous system are mainly characterized by excessive activation of microglia and elevated levels of

Correspondence to: Professor Dong-Sung Lee, Department of Pharmacy, Chosun University, 309 Pilmun-daero, Dong-gu, Gwangju 61452, Republic of Korea

E-mail: dslee2771@chosun.ac.kr

Professor Sungchul Kim, ALS/MND Center of Wonkwang University Gwangju Korean Medicine Hospital, 543-8 Juwol Dong, Nam-gu, Gwangju 61729, Republic of Korea

E-mail: kscndl@hanmail.net

${ }^{*}$ Contributed equally

Key words: mecasin, active ingredients, BV2 cells, antiinflammatory effect inflammatory factors in specific brain regions (1). Excessive activation and proliferation of microglia in numerous neurodegenerative diseases are important manifestations of inflammatory responses of central nervous system diseases such as Parkinson's disease, Alzheimer's disease, amyotrophic lateral sclerosis, cerebellar atrophy and multiple sclerosis. According to previous studies, excessive activation of microglia and continuous releases of nitric oxide (NO), inducible NO synthase (iNOS), interleukin-1 $\beta$ (IL-1 $\beta$ ) and other pro-inflammatory factors are causes of neuronal cell death (2-4). These inflammatory factors have strong toxic effects on neurons, ultimately leading to degeneration and necrosis. Therefore, inhibiting microglia hyperactivation is currently an important strategy for treating neurological diseases. Microglia may be activated by lipopolysaccharide (LPS), interferon- $\gamma$ and $\beta$-amyloid, resulting in the production of inflammatory cell mediators.

Mecasin (KCHO-1, Gamijakyakgamchobuja-tang), has anti-inflammatory and antioxidant properties. It is composed of Curcuma longa, Salvia miltiorrhiza, Gastrodia elata, Chaenomeles sinensis, Polygala tenuifolia, Paeonia japonica, Glycyrrhiza uralensis, Atractylodes japonica and processed Aconitum carmichaeli $(5,6)$. Through continuous research in recent years, various medical effects of mecasin have been discovered. For instance, it was demonstrated to have a role in reducing pain, the regeneration of gamma-aminobutyric acid neurons and NO reduction in neuropathic pain of rats (5). It also has anti-seizure, analgesic, antipyretic, anti-inflammatory, anti-ulcer, osteoarthritis-suppressing, neuro-protective and anti-neuroinflammatory effects. Its safety has also been demonstrated in both in vitro and in vivo trials (7-15).

Previous studies have indicated that mecasin acts by inducing heme oxygenase 1 expression and suppressing nuclear factor $\kappa \mathrm{B}(\mathrm{NF}-\kappa \mathrm{B})$-mediated production of proinflammatory mediators, cytokines and proteins in LPS-stimulated microglia (10). However, the contribution of each herbal medicine constituent to the effect of mecasin has remained elusive. Therefore, the objective of the present study was to determine whether constituents of mecasin may have synergistic anti-neuroinflammatory effects using LPS-stimulated BV2 cells. 


\section{Materials and methods}

Materials. Tissue culture reagents such as RPMI 1640 and fetal bovine serum (FBS) were purchased from Gibco (Thermo Fisher Scientific, Inc.). All chemicals were obtained from Sigma-Aldrich (Merck KGaA). Primary antibodies including anti-cyclooxygenase (COX)-2 (cat. no. SC-376861), anti-iNOS (cat. no. SC-7271) and anti- $\beta$-actin (cat. no. SC-47778) were purchased from Santa Cruz Biotechnology, Inc. Anti-rabbit (cat. no. AP132P) and anti-mouse (cat. no. AP124P) secondary antibodies were purchased from EMD Millipore.

Cell culture and cell viability assay. BV2 microglia were donated by Youn-Chul Kim, Wonkwang University (Iksan, Korea). BV2 microglia were seeded at $5 \times 10^{5}$ cells $/ \mathrm{ml}$ in RPMI 1640 supplemented with 10\% heat-inactivated FBS, penicillin $\mathrm{G}(100$ units $/ \mathrm{ml})$, streptomycin $(100 \mathrm{mg} / \mathrm{ml})$, and L-glutamine $(2 \mathrm{mM})$ and incubated at $37^{\circ} \mathrm{C}$ in a humidified atmosphere containing $5 \% \mathrm{CO}_{2}$. For the determination of cell viability, $50 \mathrm{mg} / \mathrm{ml}$ of MTT was added to $0.1 \mathrm{ml}$ of each well $\left(1 \times 10^{5}\right.$ cells $/ \mathrm{ml}$ in 96 -well plates) for $4 \mathrm{~h}$. The resulting formazan was dissolved in DMSO, after which the optical density of the solution was measured at $540 \mathrm{~nm}$ using an ELISA microplate reader (Model 550; Bio-Rad Laboratories Inc.). The optical density of the formazan solution from control (untreated) cells was considered to represent $100 \%$ viability.

Proportions and concentrations of individual ingredients of mecasin. Mecasin and its herbal medicine constituents were obtained from Hanpoong Pharm \& Foods. The concentration of the individual ingredients was determined based on concentrations of mecasin at 25,50, 100 and $200 \mu \mathrm{g} / \mathrm{ml}$ (Table I).

Nitrite assay. BV2 microglia were cultured in 48-well plates at a density of $5 \times 10^{5}$ cells/well $(100 \mu \mathrm{l})$ for $12 \mathrm{~h}$. Subsequently, the cells were pre-treated with indicated concentrations of each test sample for $3 \mathrm{~h}$ and then stimulated with LPS at $1 \mu \mathrm{g} / \mathrm{ml}$ for $24 \mathrm{~h}$. The amount of NO released from cells into the medium was then measured using Griess reagent $[0.1 \%$ wv $\mathrm{N}$-(1-naphathyl)-ethylenediamine and $1 \%$ (wv) sulfanilamide in $5 \%$ (vv) phosphoric acid]. The absorbance of each well was then measured at $570 \mathrm{~nm}$ using an ELISA microplate reader (Model 550; Bio-Rad Laboratories Inc.). NO was quantified using a standard curve.

Western blotting analysis. The pelleted BV2 microglia were washed with PBS, and then lysed using RIPA buffer (Thermo Fisher Scientific, Inc.; cat. no. 89900). Equal quantities of proteins $(30 \mu \mathrm{g})$ were quantified using Protein Assay Dye Reagent Concentrate obtained from Bio-Rad Laboratories, mixed in the sample loading buffer and separated by $7.5 \%$ SDS-PAGE. Separated proteins were transferred to a nitrocellulose membrane. Non-specific binding to the membrane was blocked by incubating with a solution of $5 \%$ skimmed milk at $37^{\circ} \mathrm{C}$ for $1 \mathrm{~h}$. The membrane was incubated with primary antibodies including COX-2 (1:1,000), iNOS $(1: 1,000)$ and $\beta$-actin $(1: 1,000)$ at $4^{\circ} \mathrm{C}$ overnight, and then reacted with horseradish peroxidase-conjugated rabbit (goat anti-rabbit IgG; $1: 5,000$ ) and mouse (goat anti-mouse IgG;
1:5,000) secondary antibodies at $37^{\circ} \mathrm{C}$ for $1 \mathrm{~h}$, followed by ECL detection (GENDEPOT Laboartories; cat. no. W3652-020). Quantitative densitometric analysis was conducted using ImageJ software 1.47v (National Institutes of Health).

Statistical analysis. Quantitative data are expressed as the mean \pm standard deviation of at least three independent experiments. To compare among three groups, one-way analysis of variance was used followed by Dunnett's test. All statistical analyses were performed using GraphPad Prism software, version 5.01 (GraphPad Software Inc.). $\mathrm{P}<0.05$ was considered to indicate a statistically significant difference.

\section{Results}

Comparison of cell viability. Cytotoxicity was measured using the MTT assay. The results indicated that $C$. longa and G. elata were cytotoxic at a concentration of $100 \mu \mathrm{g} / \mathrm{ml}$ or higher, while $P$. tenuifolia and $P$.japonica were cytotoxic at a concentration of $200 \mu \mathrm{g} / \mathrm{ml}$ or higher. No toxicity was observed for mecasin at concentrations of $\leq 200 \mu \mathrm{g} / \mathrm{ml}$ and the maximum concentration used in the present study was within the concentration range that caused no toxicity (Figs. 1-3).

Inhibition rate of nitrite production. BV2 cells were pre-treated with each test sample at the indicated concentrations for $3 \mathrm{~h}$ and then stimulated with LPS at $1 \mu \mathrm{g} / \mathrm{ml}$ for $24 \mathrm{~h}$. The concentration of individual ingredients was set based on concentrations of mecasin at 25, 50, 100 and $200 \mu \mathrm{g} / \mathrm{ml}$ (Table I). The inhibition rate of nitrite production was compared after this concentration was set. Mecasin at 25, 50,100 and $200 \mu \mathrm{g} / \mathrm{ml}$ contained C. longa at 4.35, 8.7, 17.4 and $34.8 \mu \mathrm{g} / \mathrm{ml}$, respectively. For mecasin, the inhibition rate of nitrite production was $14.5 \%$ at $25 \mu \mathrm{g} / \mathrm{ml}, 38.8 \%$ at $50 \mu \mathrm{g} / \mathrm{ml}$, $61.2 \%$ at $100 \mu \mathrm{g} / \mathrm{ml}$ and $88.0 \%$ at $200 \mu \mathrm{g} / \mathrm{ml}$. For C. longa, which had the greatest inhibitory effects on nitrite production among individual constituents, the inhibition rate of nitrite production was $4.2 \%$ at $4.35 \mu \mathrm{g} / \mathrm{ml}, 21.1 \%$ at $8.7 \mu \mathrm{g} / \mathrm{ml}$, $34.8 \%$ at $17.4 \mu \mathrm{g} / \mathrm{ml}$ and $71.9 \%$ at $34.8 \mu \mathrm{g} / \mathrm{ml}$. When inhibition rates of nitrite generation were compared, mecasin had a higher rate than its individual constituents. Its inhibition effect on nitrite production was dose-dependent. Among its ingredients, $C$. longa had the highest inhibition rate, followed by $P$. tenuifolia and $P$. japonica. The remaining six individual herbal components did not exert any significant inhibition on nitrite production (Table II; Figs. 4-6).

Comparison of nitrite production by mecasin and its constituents at the same concentration. BV2 microglia were cultured for $12 \mathrm{~h}$. After $12 \mathrm{~h}$, cells were pre-treated with each test sample at the indicated concentration for $3 \mathrm{~h}$ and then stimulated with LPS for $24 \mathrm{~h}$. Next, the concentration-dependent nitrite reduction effect of mecasin was compared with that of each constituent at the same concentration. The results indicated that $C$. longa, P. tenuifolia and G. uralensis had similar inhibitory effects on nitrite production, while $S$. miltiorrhiza had a relatively weak inhibitory effect on nitrite production. However, the remaining five individual constituents had no significant effect on nitrite reduction (Figs. 7-9). 
Table I. Composition of mecasin and proportions of its constituents.

\begin{tabular}{lcc}
\hline Individual ingredient & Ratio $(\%)$ & Treatment concentration by ratio of mecasin concentration $(\mu \mathrm{g} / \mathrm{ml})$ \\
\hline Curcuma longa & 17.4 & $4.35,8.7,17.4,34.8$ \\
Salvia miltiorrhiza & 17.4 & $4.35,8.7,17.4,34.8$ \\
Gastrodia elata & 17.4 & $4.35,8.7,17.4,34.8$ \\
Chaenomeles sinensis & 8.7 & $2.17,4.35,8.7,17.4$ \\
Polygala tenuifolia & 8.7 & $2.17,4.35,8.7,17.4$ \\
Paeonia japonica & 8.7 & $2.17,4.35,8.7,17.4$ \\
Glycyrrhiza uralensis & 8.7 & $2.17,4.35,8.7,17.4$ \\
Atractylodes japonica & 8.7 & $2.17,4.35,8.7,17.4$ \\
Processed Aconitum carmichaeli & 4.35 & $1.09,2.17,4.35,8.7$ \\
\hline
\end{tabular}

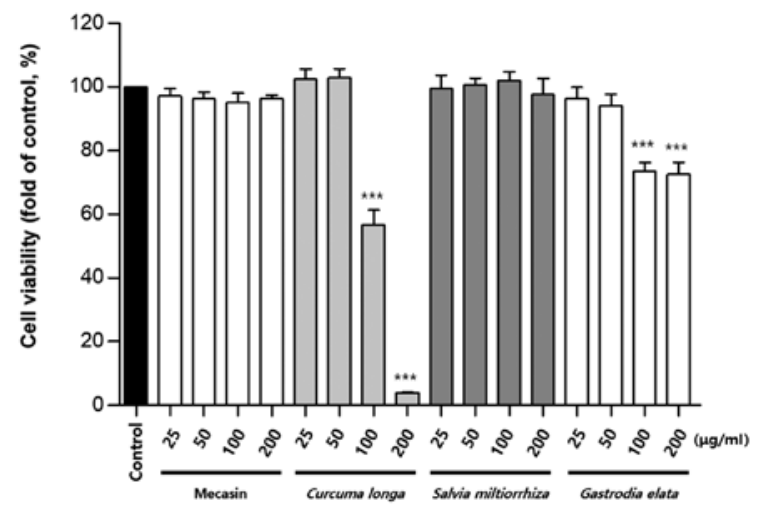

Figure 1. Comparison of cell viability after treatment with mecasin, Curcuma longa, Salvia miltiorrhiza and Gastrodia elata. BV2 cells were incubated with each sample at indicated concentrations for $24 \mathrm{~h}$. Cell viability was determined using an MTT assay. Values are expressed as the mean \pm standard deviation of three independent experiments. ${ }^{* * *} \mathrm{P}<0.001$ compared to the control (untreated group).

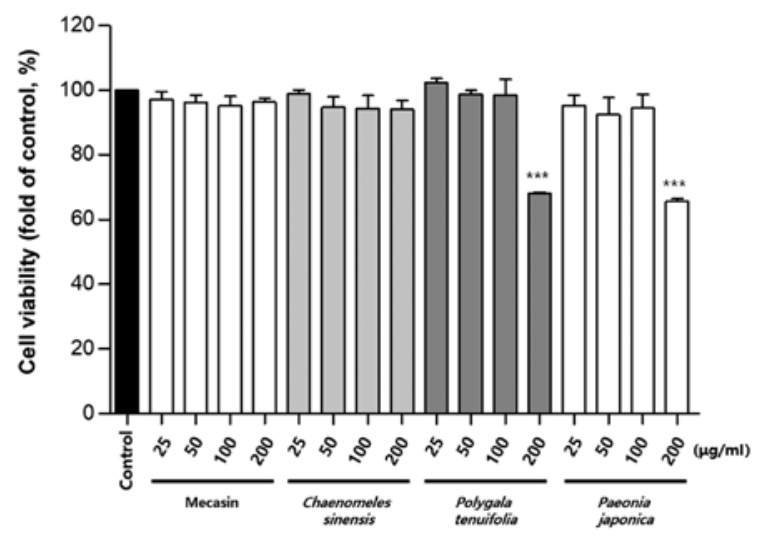

Figure 2. Comparison of cell viability after treatment with mecasin, Chaenomeles sinensis, Polygala tenuifolia and Paeonia japonica. BV2 cells were incubated with test sample at indicated concentrations for $24 \mathrm{~h}$. Cell viability was determined using an MTT assay. Values are expressed as the mean \pm standard deviation of three independent experiments. ${ }^{* * *} \mathrm{P}<0.001$ compared to the control (untreated group).

Comparison of inhibitory effects of mecasin and its constituents on $i N O S$ and COX-2 expression. It is well known that iNOS and COX-2 are responsible for the production of nitrite in LPS-induced microglia cells. Thus, it was

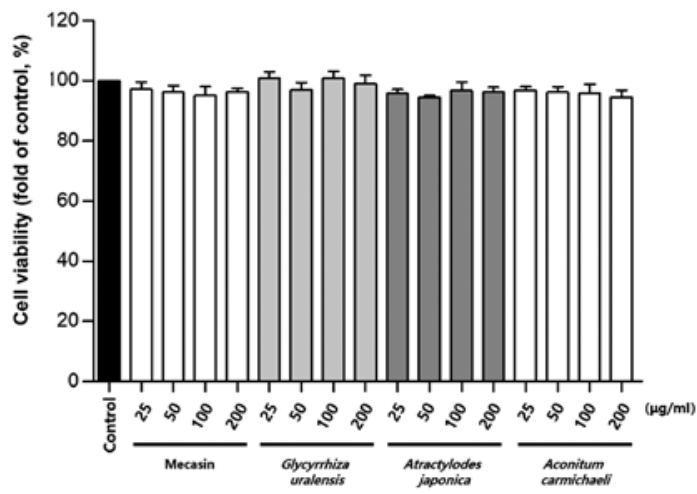

Figure 3. Comparison of cell viability after treatment with mecasin, Glycyrrhiza uralensis, Atractylodes japonica and processed Aconitum carmichaeli. BV2 cells were incubated with test sample at indicated concentrations for $24 \mathrm{~h}$. Cell viability was determined using an MTT assay. Values are expressed as the mean \pm standard deviation of three independent experiments.

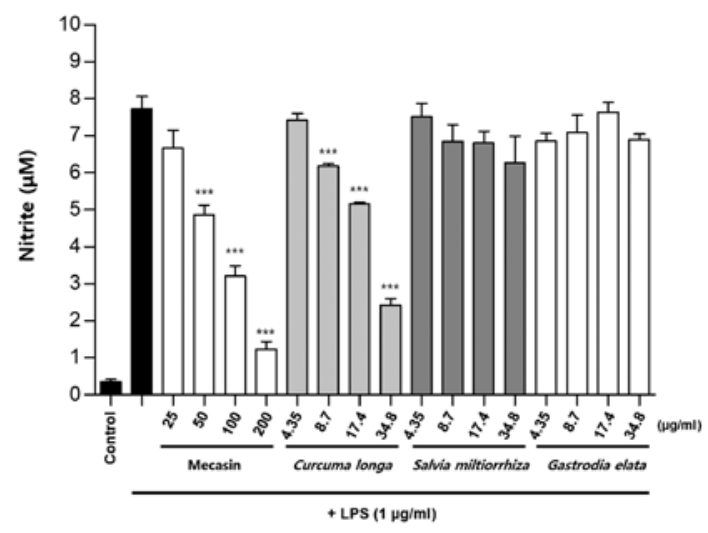

Figure 4. Effects of mecasin, Curcuma longa, Salvia miltiorrhiza and Gastrodia elata on nitrite production. Cells were pretreated with test sample at indicated concentrations for $3 \mathrm{~h}$ and stimulated with LPS at $1 \mu \mathrm{g} / \mathrm{ml}$ for $24 \mathrm{~h}$. The nitrite concentration was determined as described in the nitrate assay paragraph of the Materials and methods. Values are expressed as the mean \pm standard deviation of three independent experiments. ${ }^{* * *} \mathrm{P}<0.001$ vs. LPS group. The control is the untreated group. LPS, lipopolysaccharide.

examined whether the mecasin exerted its inhibitory effect on LPS-induced nitrite production through regulating iNOS and COX-2 expression by using western blot analysis. BV2 
Table II. Nitrite inhibition percentages of mecasin and its constituents.

Nitrite inhibition $(\%)$

Item

Concentration 1

Concentration 2

Concentration 3

Concentration 4

\begin{tabular}{|c|c|c|c|c|}
\hline Mecasin & 14.5 & 38.8 & 61.2 & 88.0 \\
\hline Curcuma longa & 4.2 & 21.1 & 34.8 & 71.9 \\
\hline Salvia miltiorrhiza & 3.0 & 12.1 & 12.6 & 19.8 \\
\hline Gastrodia elata & 11.9 & 8.8 & 1.3 & 11.4 \\
\hline Chaenomeles sinensis & 13.3 & 15.2 & 19.6 & 21.0 \\
\hline Polygala tenuifolia & 5.0 & 5.4 & 27.7 & 38.8 \\
\hline Paeonia japonica & 1.4 & 18.0 & 34.7 & 28.4 \\
\hline Glycyrrhiza uralensis & 10.4 & 17.1 & 4.8 & 14.0 \\
\hline Atractylodes japonica & 2.4 & 9.5 & 16.2 & 18.4 \\
\hline Processed Aconitum carmichaeli & 6.7 & 6.2 & 17.8 & 16.9 \\
\hline
\end{tabular}

Concentration 1 [mecasin $(25 \mu \mathrm{g} / \mathrm{ml})$ ]: Curcuma longa $(4.35 \mu \mathrm{g} / \mathrm{ml})$, Salvia miltiorrhiza $(4.35 \mu \mathrm{g} / \mathrm{ml})$, Gastrodia elata (4.35 $\mu \mathrm{g} / \mathrm{ml})$, Chaenomeles sinensis $(2.17 \mu \mathrm{g} / \mathrm{ml})$, Polygala tenuifolia $(2.17 \mu \mathrm{g} / \mathrm{ml})$, Paeonia japonica $(2.17 \mu \mathrm{g} / \mathrm{ml})$, Glycyrrhiza uralensis $(2.17 \mu \mathrm{g} / \mathrm{ml})$, Atractylodes japonica $(2.17 \mu \mathrm{g} / \mathrm{ml})$ and processed Aconitum carmichaeli $(1.09 \mu \mathrm{g} / \mathrm{ml})$. Concentration 2 [mecasin $(50 \mu \mathrm{g} / \mathrm{ml})$ ]: Curcuma longa $(8.7 \mu \mathrm{g} / \mathrm{ml})$, Salvia miltiorrhiza $(8.7 \mu \mathrm{g} / \mathrm{ml})$, Gastrodia elata $(8.7 \mu \mathrm{g} / \mathrm{ml})$, Chaenomeles sinensis $(4.35 \mu \mathrm{g} / \mathrm{ml})$, Polygala tenuifolia $(4.35 \mu \mathrm{g} / \mathrm{ml})$, Paeonia japonica $(4.35 \mu \mathrm{g} / \mathrm{ml})$, Glycyrrhiza uralensis $(4.35 \mu \mathrm{g} / \mathrm{ml})$, Atractylodes japonica $(4.35 \mu \mathrm{g} / \mathrm{ml})$ and $\mathrm{processed} \mathrm{Aconitum}$ carmichaeli $(2.17 \mu \mathrm{g} / \mathrm{ml})$. Concentration 3 [mecasin $(100 \mu \mathrm{g} / \mathrm{ml})]$ : Curcuma longa $(17.4 \mu \mathrm{g} / \mathrm{ml})$, Salvia miltiorrhiza $(17.4 \mu \mathrm{g} / \mathrm{ml})$, Gastrodia elata $(17.4 \mu \mathrm{g} / \mathrm{ml})$, Chaenomeles sinensis $(8.7 \mu \mathrm{g} / \mathrm{ml})$, Polygala tenuifolia $(8.7 \mu \mathrm{g} / \mathrm{ml})$, Paeonia japonica $(8.7 \mu \mathrm{g} / \mathrm{ml})$, Glycyrrhiza uralensis $(8.7 \mu \mathrm{g} / \mathrm{ml})$, Atractylodes japonica $(8.7 \mu \mathrm{g} / \mathrm{ml})$ and processed Aconitum carmichaeli $(4.35 \mu \mathrm{g} / \mathrm{ml})$. Concentration 4 [mecasin $(200 \mu \mathrm{g} / \mathrm{ml})]$ : Curcuma longa $(34.8 \mu \mathrm{g} / \mathrm{ml})$, Salvia miltiorrhiza $(34.8 \mu \mathrm{g} / \mathrm{ml})$, Gastrodia elata $(34.8 \mu \mathrm{g} / \mathrm{ml})$, Chaenomeles sinensis $(17.4 \mu \mathrm{g} / \mathrm{ml})$, Polygala tenuifolia $(17.4 \mu \mathrm{g} / \mathrm{ml})$, Paeonia japonica $(17.4 \mu \mathrm{g} / \mathrm{ml})$, Glycyrrhiza uralensis $(17.4 \mu \mathrm{g} / \mathrm{ml})$, Atractylodes japonica $(17.4 \mu \mathrm{g} / \mathrm{ml})$ and processed Aconitum carmichaeli $(8.7 \mu \mathrm{g} / \mathrm{ml})$.

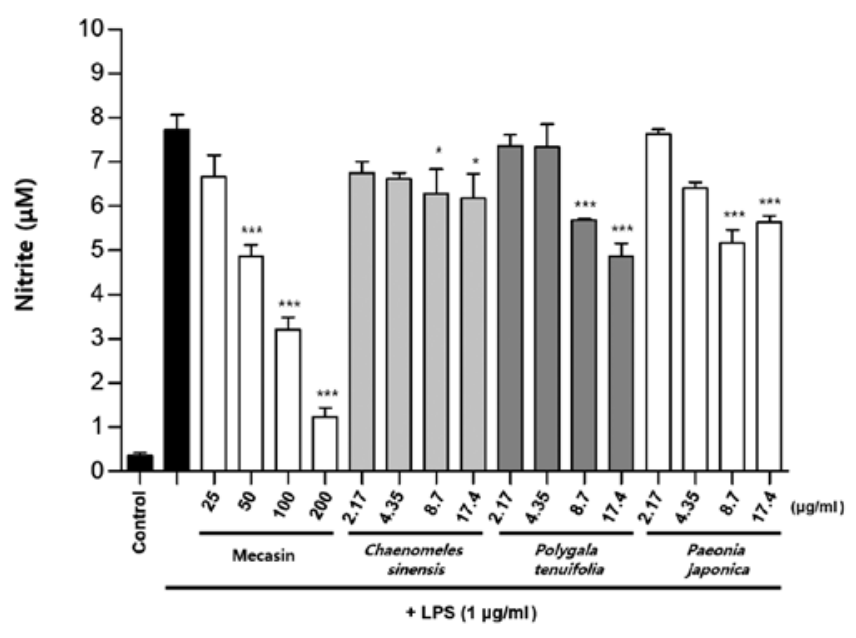

Figure 5. Effects of mecasin, Chanomeles sinensis, Polygala tenuifolia and Paeonia japonica on nitrite production. Cells were pretreated with test sample at the indicated concentration for $3 \mathrm{~h}$ and stimulated with LPS at $1 \mu \mathrm{g} / \mathrm{ml}$ for $24 \mathrm{~h}$. The nitrite concentration was determined as described in the nitrate assay paragraph of the Materials and methods. Values are expressed as the mean \pm standard deviation of three independent experiments. ${ }^{*} \mathrm{P}<0.05$ and ${ }^{* * *} \mathrm{P}<0.001$ vs. LPS group. The control is the untreated group. LPS, lipopolysaccharide.

microglia were pre-treated with each sample at the indicated concentration for $3 \mathrm{~h}$ and then stimulated with LPS at $1 \mu \mathrm{g} / \mathrm{ml}$ for $24 \mathrm{~h}$. As presented in Fig. 10, pre-treatment with mecasin or certain constituents thereof suppressed the expression of iNOS and COX-2 in a pattern similar to the inhibition rate of nitrite production.

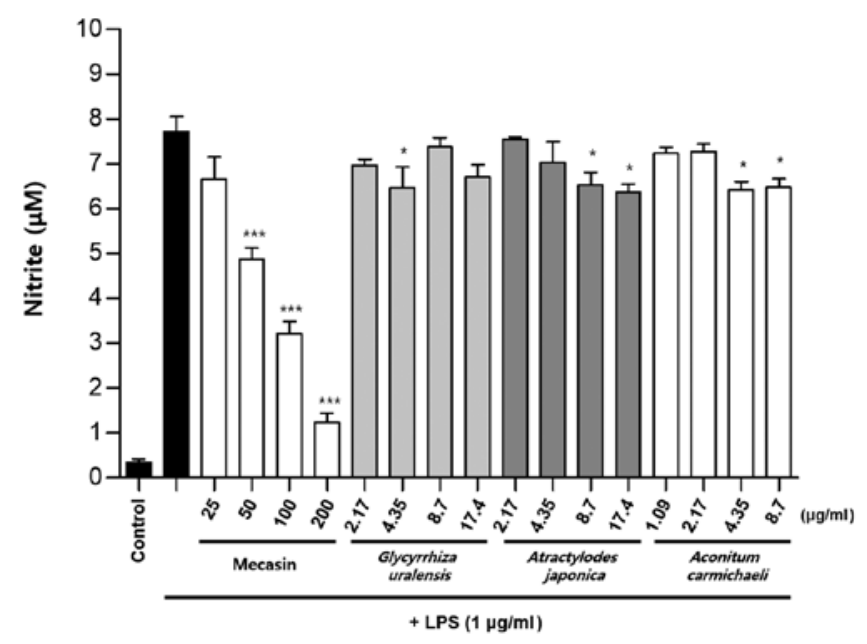

Figure 6. Effects of mecasin, Glycyrrhiza uralensis, Atractylodes japonica and processed Aconitum carmichaeli on nitrite production. Cells were pretreated with test sample at the indicated concentrations for $3 \mathrm{~h}$ and stimulated with LPS at $1 \mu \mathrm{g} / \mathrm{ml}$ for $24 \mathrm{~h}$. The nitrite concentration was determined as described in the nitrate assay paragraph of the Materials and methods. Values are expressed as the mean \pm standard deviation of three independent experiments. ${ }^{*} \mathrm{P}<0.05$ and ${ }^{* * *} \mathrm{P}<0.001$ vs. LPS group. The control is the untreated group. LPS, lipopolysaccharide.

\section{Discussion}

BV2 microglia are main immune effector cells in the brain. They have a major role in the pathogenesis of a wide range of chronic neuroinflammation and neurodegenerative diseases. A general feature of BV2 microglia in the inflammation of 


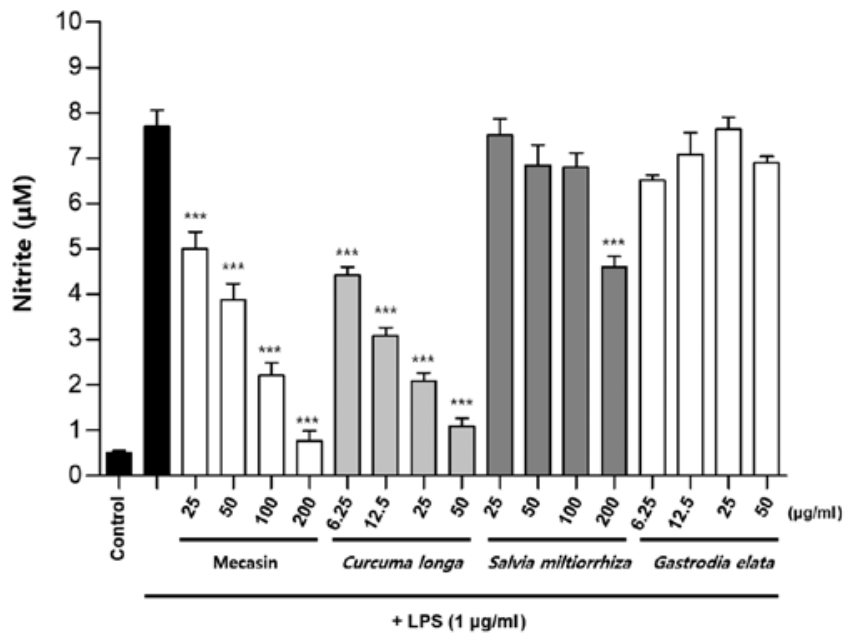

Figure 7. Inhibitory effects on mecasin, Curcuma longa, Salvia miltiorrhiza and Gastrodia elata at the same concentration on nitrite formation. Cells were pretreated with each sample at indicated concentrations for $3 \mathrm{~h}$ and stimulated with LPS at $1 \mu \mathrm{g} / \mathrm{ml}$ for $24 \mathrm{~h}$. The nitrite concentration was determined as described in the nitrate assay paragraph of the Materials and methods. Values are expressed as the mean \pm standard deviation of three independent experiments. ${ }^{* * *} \mathrm{P}<0.001$ vs. LPS group. The control is the untreated group. LPS, lipopolysaccharide.

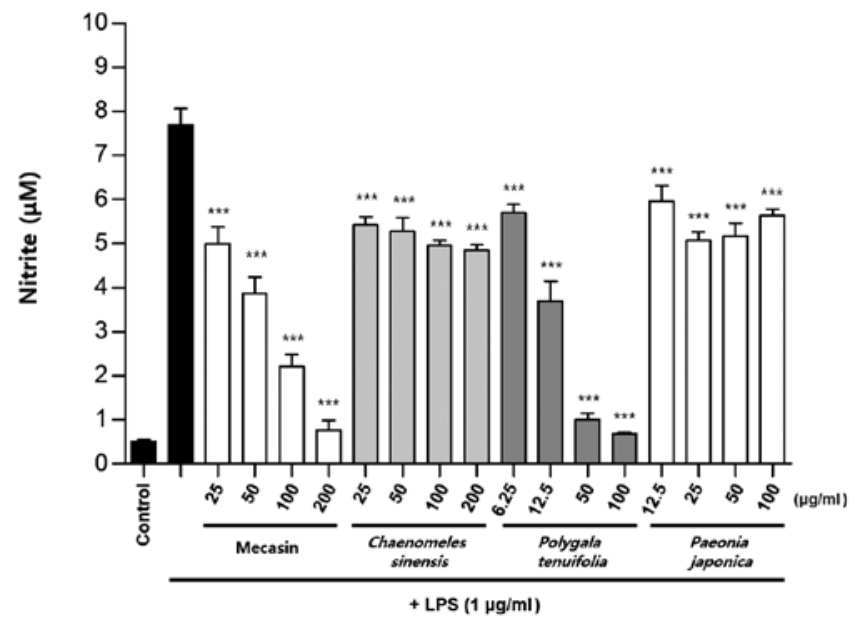

Figure 8. Inhibitory effects of mecasin, Chanomeles sinensis, Polygala tenuifolia and Paeonia japonica at the same concentration on nitrite formation. Cells were pretreated with each test sample at indicated concentrations for $3 \mathrm{~h}$ and stimulated with LPS at $1 \mu \mathrm{g} / \mathrm{ml}$ for $24 \mathrm{~h}$. The nitrite concentration was determined as described in the nitrate assay paragraph of the Materials and methods. Values are expressed as the mean \pm standard deviation of three independent experiments. ${ }^{* * *} \mathrm{P}<0.001$ vs. LPS group. The control is the untreated group. LPS, lipopolysaccharide.

the central nervous system is the long-term activation of BV2 microglia and consequently increased inflammatory expansion, leading to increased release of inflammatory mediators. Therefore, BV2 microglia have a crucial role in the development of neuroinflammation and neurodegenerative diseases. BV2 microglia are known to secrete NO, tumor necrosis factor- $\alpha$ (TNF- $\alpha$ ), IL- $1 \beta$ and other active substances involved in the pathogenesis of nervous system diseases $(16,17)$. The expression of NOS is significantly increased in lesions of nervous system diseases. NOS is known to promote the production of NO. NO is able to form a strong oxidant that

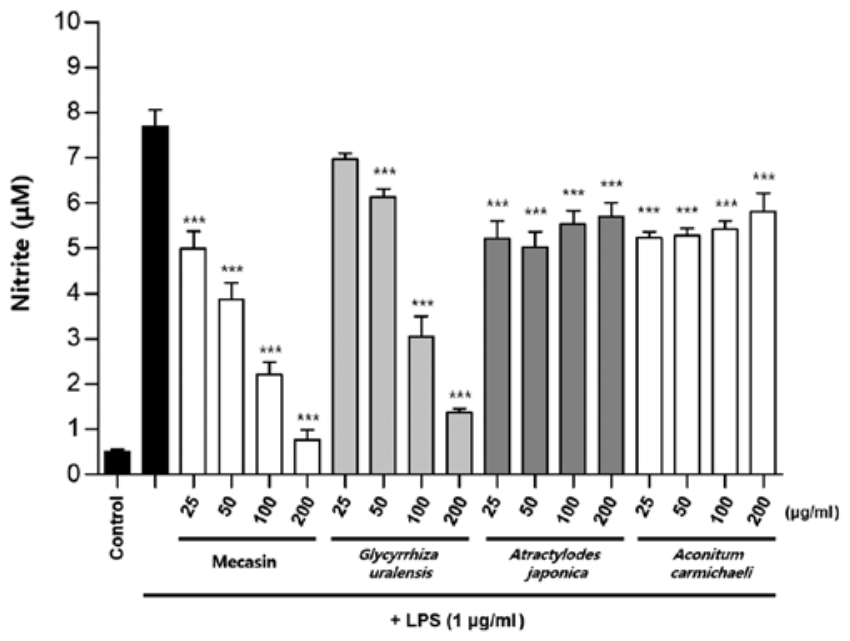

Figure 9. Inhibitory effects of mecasin, Glycyrrhiza uralensis, Atractylodes japonica and processed Aconitum carmichaeli at the same concentration on nitrite formation. Cells were pretreated with each test sample at the indicated concentrations for $3 \mathrm{~h}$ and stimulated with LPS at $1 \mu \mathrm{g} / \mathrm{ml}$ for $24 \mathrm{~h}$. The nitrite concentration was determined as described in the nitrate assay paragraph of the Materials and methods. Values are expressed as the mean \pm standard deviation of three independent experiments. ${ }^{* * *} \mathrm{P}<0.001$ vs. LPS group. The control is the untreated group. LPS, lipopolysaccharide.

causes tissue oxidative damage after a series of reactions (18). TNF- $\alpha$ and IL- $1 \beta$ are strong pro-inflammatory factors that may increase the release of NO and aggravate inflammatory response and neuronal damage (19). Therefore, in the present study, BV2 microglia were chosen as an in vitro cell model. NO acts as a highly reactive free radical in the body. It is both a second messenger and a neurotransmitter. It is also an effector molecule that is widely used in the body. It has various physiological effects, such as relaxing vascular smooth muscle, inhibiting platelet aggregation, regulating cerebral blood flow, mediating cytotoxic effects and regulating the immune system. NO itself has a short half-life. NO in the blood is mainly produced by vascular endothelial cells, vascular smooth muscle cells, platelets and macrophages in the form of nitrite and nitrate. According to the principle that NO will form nitrite when it is dissolved in water, the content of NO was indirectly reflected by the nitrite content measured in the present study $(19,20)$.

A previous study by our group have suggested that mecasin has anti-inflammatory and anti-oxidant effects (10). Jakyak-Gamcho-tang, a prescription that is the origin of mecasin, has been used mainly for alleviating pain, muscle spasms and cold syndrome due to blood deficiency for centuries in traditional oriental medicine (21). A previous study has indicated that mecasin is able to reduce the release of NO in activated microglial cells (10). However, the role of each ingredient regarding the total effect of mecasin has remained elusive. The results of the present study suggested that constituents of mecasin have synergistic anti-neuroinflammatory effects.

First, the concentration of individual ingredients was set based on mecasin concentrations of 25, 50, 100 and $200 \mu \mathrm{g} / \mathrm{ml}$. Next, the toxicities of mecasin and its nine individual medicinal herb constituents were measured using an MTT assay. LPS-stimulated BV2 cells were selected as an experimental model to study effects of mecasin and 

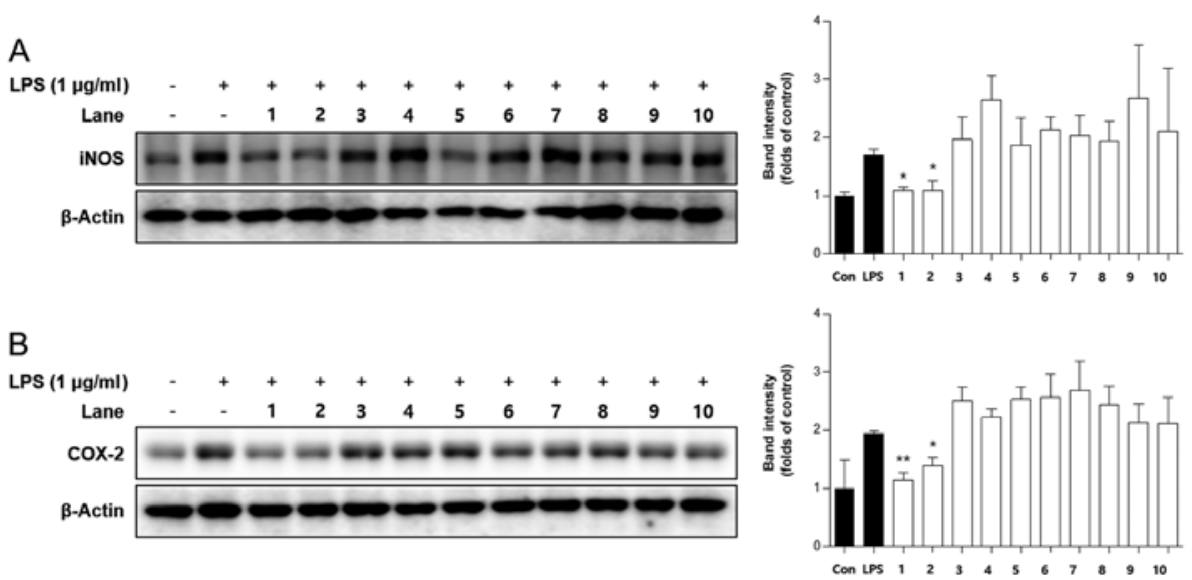

\begin{tabular}{|c|c|c|}
\hline Lane & Configuration individual ingredients & Concentration \\
\hline $\mathbf{1}$ & Mecasin & $200 \mu \mathrm{\mu g} / \mathrm{ml}$ \\
\hline $\mathbf{2}$ & Curcuma longa & $34.8 \mu \mathrm{\mu g} / \mathrm{ml}$ \\
\hline $\mathbf{3}$ & Salvia miltiormiza & $34.8 \mu \mathrm{g} / \mathrm{ml}$ \\
\hline $\mathbf{4}$ & Gastrodia elata & $34.8 \mu \mathrm{g} / \mathrm{ml}$ \\
\hline $\mathbf{5}$ & Chaenomeles sinensis & $17.4 \mu \mathrm{g} / \mathrm{ml}$ \\
\hline $\mathbf{6}$ & Polygala tenuifolia & $17.4 \mu \mathrm{g} / \mathrm{ml}$ \\
\hline $\mathbf{7}$ & Paeonia japonica & $17.4 \mu \mathrm{g} / \mathrm{ml}$ \\
\hline $\mathbf{8}$ & Glycyrrmiza uralensis & $17.4 \mu \mathrm{g} / \mathrm{ml}$ \\
\hline $\mathbf{9}$ & Atractylodes japonica & $17.4 \mu \mathrm{g} / \mathrm{ml}$ \\
\hline $\mathbf{1 0}$ & Processed Aconitum carmichaeli & $8.7 \mu \mathrm{g} / \mathrm{ml}$ \\
\hline
\end{tabular}

Figure 10. Comparison of the inhibitory effects of mecasin and its constituents on the expression of iNOS and COX-2. Cells were pretreated with test samples at the indicated concentrations for $3 \mathrm{~h}$ and stimulated with LPS at $1 \mu \mathrm{g} / \mathrm{ml}$ for $24 \mathrm{~h}$. Western blot analysis was performed as described in the western blotting section of the Materials and methods section. Representative blots from three independent experiments are presented. (A) Blots of iNOS and $\beta$-actin. (B) Blots of COX-2 and $\beta$-actin. Band intensities were normalized to $\beta$-actin. Values are expressed as the mean \pm standard deviation. ${ }^{*} \mathrm{P}<0.05$ and ${ }^{* *} \mathrm{P}<0.01$ vs. the LPS-treated control. iNOS, inducible nitrite oxide synthase; COX, cyclooxygenase; LPS, lipopolysaccharide.

its constituents on the release of inflammatory products. The results indicated that mecasin had the most potent effect. Among the single herbs, C. longa, P. tenuifolia and $P$. japonica also exhibited marked effects. Joseph et al (22) suggested that $C$. longa may act as a pro-drug, as its metabolite has anti-inflammatory activity. The metabolite produced by the oxidation of curcumin derived from C. long $a$ is able to bind to $\mathrm{NF}-\kappa \mathrm{B}$ in a covalent bond, thereby further suppressing inflammatory reactions (22). Mecasin demonstrated a higher inhibitory effect on nitrite generation than its nine medicinal herb constituents. Next, we also checked that the effect of mecasin and its constituents (nine individual medicinal herbs) on iNOS and COX-2 expression was assessed. As presented in Fig. 10, mecasin and $C$. longa demonstrated the most prominent inhibitory effects. Furthermore, mecasin demonstrated higher inhibitory effects compared with $C$. longa. The results suggested that treatment with mecasin inhibited the protein expression of iNOS and COX-2 to a greater extent than its nine herbal constituents separately. These results demonstrated that the most potent inhibitor of nitrite production and iNOS and COX-2 expression was mecasin, probably due to synergistic effects of its herbal medicinal constituents.

The effects of mecasin and its constituents on LPS-stimulated nitrite production and expression levels of iNOS and COX-2 on BV2 microglia cells at the same concentration were examined. Mecasin is not a simple combination of nine herbs with pharmacological effects. The first experiment was performed to observe neuroinflammatory effects of mecasin and its constituents at corresponding concentrations. It was indicated that mecasin (mixture of 9 components) had a higher effect than its individual herbal constituents. The second experiment was performed to observe their neuroinflammatory effects at the same concentration. The results suggested that three single individual herbal constituents had similar effects to those of mecasin. However, these three constituents exhibited higher cytotoxicity than mecasin at the same concentration. This result indicated that synergistic effects of constituents of mecasin may increase the effectiveness and safety of mecasin, indicating that mecasin has potential for treating neuroinflammation. To draw any reliable conclusions regarding the potential value of mecasin in neurological diseases, the results should be reperformed at least in another microglial cell line such as HMC3. Therefore, in a follow-up study, other microglial cells such as HMC3 cells will be used.

Finally, Chinese medicine is well known for reducing side effects and enhancing the efficacy of several drugs $(23,24)$. In certain studies, some of the results regarding the lowering of highly toxic drug side effects and the enhancing of drug efficacy have been confirmed $(23,24)$. Mecasin is a new combinational drug. However, a detailed mechanistic study on the synergistic effect of mecasin is required in future research.

\section{Acknowledgements}

Not applicable.

\section{Funding}

This research was supported by a grant from the Jeonbuk Research \& Development Program funded by Jeonbuk province (grant no. RA202006-24-C4).

\section{Availability of data and materials}

The datasets used and/or analyzed during the present study are available from the corresponding author on reasonable request.

\section{Authors' contributions}

TW and WK designed the experiments. DSL, JYS, DC and SK performed the nitrite and MTT assays. TW and WK drafted the manuscript or revised it critically for important intellectual content. DSL and SK gave final approval of the version to be published. All the authors verified and approved the final version of the manuscript. All the authors checked and approved the authenticity of the raw data. 


\section{Ethics approval and consent to participate}

Not applicable.

\section{Patient consent for publication}

Not applicable.

\section{Competing interests}

The authors declare that they have no competing interests.

\section{References}

1. Yoon HM, Jang KJ, Han MS, Jeong JW, Kim GY, Lee JH and Choi YH: Ganoderma lucidum ethanol extract inhibits the inflammatory response by suppressing the NF- $\mathrm{BB}$ and toll-like receptor pathways in lipopolysaccharide-stimulated BV2 microglial cells. Exp Ther Med 5: 957-963, 2013.

2. Amor S, Peferoen LAN, Vogel DYS, Breur M, van der Valk P, Baker D and van Noort JM: Inflammation in neurodegenerative diseases-an update. Immunology 142: 151-166, 2014.

3. Griffiths MR, Gasque P and Neal JW: The multiple roles of the innate immune system in the regulation of apopyosis and inflammation in the brain. J Neuropathol Exp Neurol 68: 217 226, 2009

4. Hernagomez M, Carrillo-Salinas FJ, Mevha M, Correa F, Mestre L, Loría F, Feliú A, Docagne F and Guaza C: Brain innate immunity in the regulation of neuroinflammation: Therapeutic strategies by modulating CD200-CD200R interaction involve the cannabionoid system. Curr Pharm Des 20: 4707-4722, 2014.

5. Kim DH: Effect of Gamijakyakgamchobuja-tang on neuropathic pain in rats. Korean; Jeollabuk-do, Wonkwang Univ, 2015.

6. Lee DS, Ko W, Song BK, Son I, Kim DW, Kang DG, Lee HS Oh H, Jang JH, Kim YC and Kim S: The herbal extract KCHO-1 exerts a neuroprotective effect by ameliorating oxidative stress via heme oxygenase-1 upregulation. Mol Med Rep 13: 4911-4919, 2016.

7. Yu JW: Study on the ingredient of Jakyakgamchotang. Jeollabuk-do. Wonkwang Univ. Korean, 2010.

8. Kim BW: Anti-inflammatory effect of Jakyakgamcho-tang. J Int Korean Med 31: 365-371, 2010.

9. Lee JM, Hong SY and Oh MS: Effects of Jakyakkamchobuja-tang on Papain-induced osteoarthritis in mice. J Korean Med 34: $116-135,2013$

10. Lee DS, Ko W, Yoon CS, Kim DC, Yun J, Lee JK, Jun KY, Son I, Kim DW, Song BK, et al: KCHO-1, a novel anti-neuroinflammatory agent, inhibits Lipopolysaccharide induced neuroinflammatory responses through $\mathrm{Nrf} 2$-mediated heme oxygenase-1 expression in mouse BV2 microglia cells. Evid Based Complement Alternat Med 2014: 357154, 2014

11. Cha E, Lee J, Lee S, Park M, Song I, Son I, Song BK, Kim D, Lee J and Kim S: A 4-week repeated dose oral toxicity study of Mecasin in Sprague-Dawley rats to determine the appropriate doses for a 13-week, repeated toxicity test. J Pharmacopuncture 18: 45-50, 2015.
12. Jeong H, Lee J, Cha E, Park M, Son I, Song B and Kim S: A study on the oral toxicity of mecasin in rats. J Pharmacopuncture 17 61-65, 2014.

13. Cha E, Jeong H, Lee J, Lee S, Park M and Kim S: A study on single dose toxicity of Mecasin pharmacopuncture injection in muscle. J Korean Med 36: 36-42, 2015.

14. Lee SJ, Jeong HH, Lee JC, Cha EH, Park MY and Song BG: A study on single dose toxicity of intravenous injection of Mecasin herbal acupuncture. J Korean Acupunct Moxibustion Med 33: $1-7,2016$.

15. Kook MG, Choi SW, Seo Y, Kim DW, Song BK, Son I, Kim S and Kang KS: KCHO-1, a novel herbal anti-inflammatory compound, attenuates oxidative stress in an animal model of amyotrophic lateral sclerosis. J Vet Sci 18: 487-497, 2017.

16. Liu HY, Chen CY and Hsueh YP: Innate immune responses regulate morphogenesis and degeneration: Roles of Toll-like receptors and Sarml in neurons. Neurosci Bull 30: 645-654, 2014.

17. van Ham TJ, Brady CA, Kalicharan RD, Oosterhof N, Kuipers J Veenstra-Algra A, Sjollema KA, Peterson RT, Kampinga HH and Giepmans BNG: Intravital correlated microscopy reveals differential macrophage and microgial dynamics during resolution of neuroinflammation. Dis Model Mech 7: 857-869, 2014.

18. Broholm H, Andersen B, Wanscher B, Frederiksen JL, Rubin I, Pakkenberg B, Larsson HB and Lauritzen M: Nitric oxide synthase expression and enzymatic activity in multiple Sclerosis. Acta Neural Scand 109: 261-269, 2004.

19. Baud V and Karin M: Signal transduction by tumor necrosis factor and its relatives.Trends Cell Biol 11: 372-377, 2001.

20. Braddock M and Quinn A: Targeting IL-1 in inflammatory disease: New opportunities for therapeutic intervention. Nat Rev Drug Discov 3: 330-339, 2004.

21. Guo L, Cho SY, Kang SS, Lee SH, Baek HY and Kim YS: Orthogonal array design for optimizing extraction efficiency of active constituents from Jakyak-Gamcho Decoction, the complex formula of herbal medicines, Paeoniae Radix and Glycyrrhizae Radix. J Ethnopharmacol 113: 306-311, 2007.

22. Joseph AI, Edwards RL, Luis PB, Presley SH, Porter NA and Schneider C: Stability and anti-inflammatory activity of the reduction-resistant curcumin analog, 2,6-dimethyl curcumin. Org Biomol Chem 16: 3273-3281. 2018.

23. Liu J, Liu J, Shen F, Qin Z, Jiang M, Zhu J, Wang Z, Zhou J, Fu Y, Chen X, et al: Systems pharmacology analysis of synergy of TCM: An example using saffron formula. Sci Rep 8: 380, 2018.

24. Bhuyan DJ, Perera S, Kaur K, Alsherbiny MA, Low M, Seto SW, Li CG and Zhou X: Synergistic Effects of Chinese Herbal Medicine and Biological Networks. In: Approaching Complex Diseases. Bizzarri M (ed). Springer, Cham, pp393-436, 2020.

This work is licensed under a Creative Common Attribution-NonCommercial-NoDerivatives 4.0 International (CC BY-NC-ND 4.0) License. 